\title{
A brief history of a restless vision: seismological research in Venezuela
}

\author{
Rogelio Altez $\left({ }^{1}\right)$ and José Grases $\left({ }^{2}\right)$ \\ (1) Escuela de Antropología, Universidad Central de Venezuela, Caracas, Venezuela \\ ${ }^{2}{ }^{2}$ Academia de Ciencias Físicas, Matemáticas y Naturales de Venezuela
}

\begin{abstract}
Seismological research in Venezuela has managed to survive in the Twentieth century in spite of having produced only two catalogues for public consultation in a period of sixty years, the last of them being published in 1999. However, great investigators, national and foreign, gave their best years to scientific knowledge. Through their restlessness and attitudes, the perspective of the science of earthquakes was constructed. Watching through their eyes, and by means of the 1812 earthquakes, the most controversial and important in this country, the history of the Venezuelan seismology is revealed in this paper. Amidst discussions and ruins, opening footpaths on destructive earthquakes, Venezuelan seismology began to build its own vision.
\end{abstract}

Key words Venezuela - earthquake catalogue seismological methodology - historical seismology

\section{Introduction: the interpretative transformation}

The 26th of March 1812 was Holy Thursday in Venezuela. A few months before, in July of 1811, the First Republic had been declared. This was to rupture with the colonial past. On the afternoon of the 26th, with cathedrals filled with people, a slightly confused society was preparing itself to profess its faith and, perhaps, to kneel in prayer for its uncertain destiny. In the mean time, the new Republican authorities were nervously discussing how to confront a Spanish army that was already approaching the capital from the west. A few minutes after four o'clock in the afternoon,

Mailing address: Dr. Rogelio Altez, Escuela de Antropología, Facultad de Ciencias Económicas y Sociales, Universidad Central de Venezuela, Residencias Vargas II, Los Chaguaramos, Caracas, Venezuela; e-mail:ryaltez@cantv.net in Caracas, bishops and worshippers observed how the churches collapsed, burying thousands. Simultaneouslpy, the cities of Barquisimeto, La Guaira and San Felipe were converted into a pile of ruins. Almost one hour later, Mérida saw a similar scene, when at five o'clock in that same afternoon, everything turned into dust and rubbish. Over a distance of about $800 \mathrm{~km}$, and with an imperceptible, at that time, difference of approximately one hour, two great earthquakes followed by several aftershocks tumbled the ambitions of the rebel criollos and, at the same time, turned out to be the last earthquakes of the colonial record and the first of the republican era.

This was not only a historical landmark, but also a hermeneutic landmark. With the coming of modernity, American societies were not only shaken institutionally, but also underwent a deep ideological transformation. With the advent of the Nineteenth century, new forms of thinking and new behaviours appeared. For that reason, Latin America's excolonial societies began early on to readjust their societal relationships and to re-legitimise 
powers. This process, occurring from the inside out, was totally focused on political and economic issues, so that the observation of the development of a scientific mindset was far from being a priority in the first decades. Thus, the observation and study of nature had little space in daily life in the convulsive postcolonial republics.

The Venezuelan situation fits accurately within this description. The 1812 disaster, which had foiled the first emancipating attempt of the criollos, at the same time, ended a way of life and a way of understanding nature's acts and therefore, a way of constructing reality. The ideological transformation of the colonial society into a liberal society, which lasted throughout the Nineteenth century, turned out to be a political project, and counted among its priorities only institutional consolidation and an unattainable economic stability, over any other type of development or social growth. Intellectual activities were, at that time, so involved with the political process that academic life or scientific thought had little to do. In that sense, the observation of nature seems displaced by the more immediate problems.

This situation, which captured society's attention in the early years of the Republic, began to change, and spaces opened up for academic life in the second half of the Nineteenth century. The development of natural sciences, imposed perhaps by an eagerness for status and guided by the rhythm of phenomena, made important steps following great events.

Concerning seismic ones, after 1812 there were no destructive earthquakes until 1853, when the city of Cumaná suffered one of the most important quakes in Venezuelan history. Some comments, attempts at erudite explanations, came to the public light in those days. Nevertheless, it was only with the appearance of the Sociedad de Ciencias Físicas y Naturales (Physical and Natural Sciences Society), whose origin dates back to 1866 , that hypotheses about the behaviour of nature had a formal frame for their discussion. Thus, the eyes that observed the natural phenomena initiated their modern reading of reality.

\section{From the Enlightenment to the Academy}

Many were the travellers who walked the American roads between the Eighteenth and the Nineteenth century. Men of the enlightenment and other adventurers lived years of astonishment in the New World. Everything nature offered became an exotic window for interpretation and experimentation. Armed with an exuberant and romantic rhetoric, their narratives drew scenes that tread between the magic and the descriptive. For that reason, natural phenomena caught their attention, and their efforts to explain them were quickly transformed into technical manuals, methodological guides and objects of discussion and contrast.

The most obvious case is that of the German scholar Alexander von Humboldt, who generously contributed to the knowledge of the equatorial regions. His travels in Venezuela allowed him to witness several interesting events, among them, some remarkable earthquakes. Nevertheless, his most remarked opinions on the matter can be found in his work «Viaje a las regiones equinocciales del Nuevo Continente» (Humboldt, 1956) - the first edition of which is dated 1814 - on the earthquake of 1812 , in spite of his not having been present at that time in Venezuela. Generally, Humboldt's text should be considered a credible secondary source of those phenomena, since it contains accounts from direct witnesses who, later, would have their own say on the matter. It could be said that it was with the German scholar that observations on nature in these latitudes were inaugurated. His intellectual contributions on natural phenomena, geology and geography served as the departure point for many later followers or detractors.

Nevertheless, the text of Manuel Palacio Fajardo (1816) regarding the events of 26 March 1812 must be considered to be the first Venezuelan contribution to the discussion of earthquakes. He not only personally gave Humboldt a manuscript that described the earthquakes, during an encounter in Paris in 1813 (Altez, 1999), which in fact, is one of the references that the German scholar used in his work, but he also published his own conclusions in «An account of the earthquake of Caracas» (Palacio Fajardo, 1816). In addition to being an 
open supporter of the independence movement, Palacio Fajardo was the chair of the medical department of the Real Colegio de Mérida (Real College of Mérida), in 1808, and counted among his diplomas those of medical doctor and doctor of civil and canonical law (Urbani, 1990). Certainly, he was a well informed criollo who initiated, without knowing it, a long discussion of almost two hundred years on the 1812 earthquakes, and who, like a strategic bridge, helped to cross the boundary between pre-modern thought and modernity.

That boundary was being crossed not only by Venezuelan thinkers, but also by all western culture, which began to understand itself and its natural surroundings, from a standpoint more concrete than mystical, more physical than metaphysical, and more scientific than religious. For that reason, when on 15 July 1853 the city of Cumaná was levelled by an earthquake, the few accounts mentioned in newspapers of the time

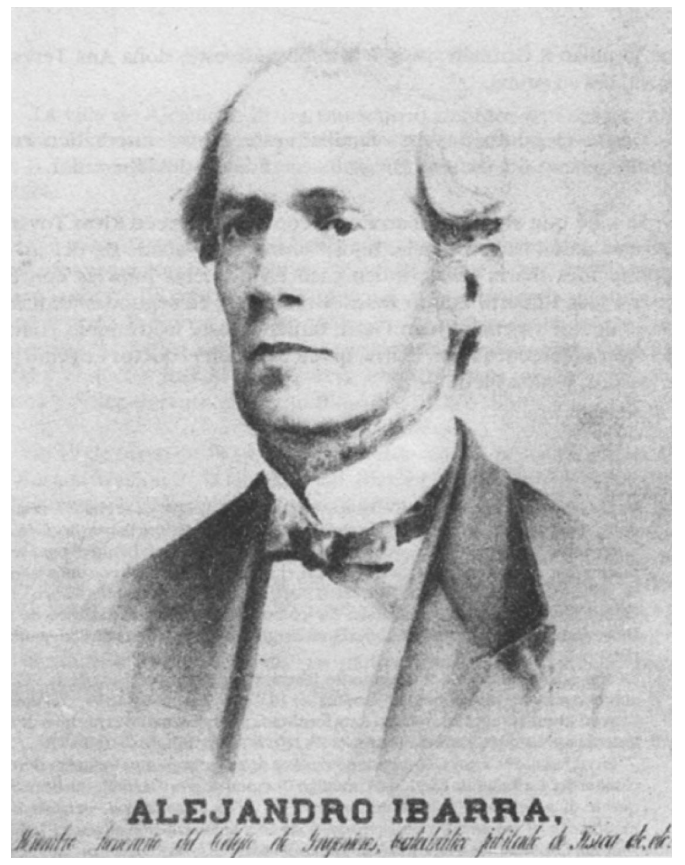

Fig. 1. Alejandro Ibarra 1813-1880, seismologist (from Leal, 1994). were from the pen of a very reliable witness: Daniel Beauperthuy (1807-1871), who, at the time, lived in that city and who later discovered the mechanism for the transmission of yellow fever (Lemoine and Suárez, 1984). The first commentaries on this event, as well as the first references to seismic issues in Venezuela, was written by Alejandro Ibarra (1813-1880), physicist, mathematician and philosopher, the person who inaugurated with his writings the Venezuelan seismological vision (fig. 1).

Ibarra would publish, in the newspaper $D i$ ario de Avisos, an article titled «Temblores y lluvias en Caracas» (Earthquakes and rains in Caracas, 1854), in which he attempted to explain the reasons for the occurrence of several natural phenomena with a rigorous academic style. His quality as academician and intellectual authority of the University of Caracas, gave his discourse a formality that was already demanding space and recognition in a growing academic and intellectual context. Later, in 1862, his work, in ten articles entitled Temblores y terremotos (Tremors and earthquakes, 1862), was published in the newspaper El Independiente (Caracas), and, as a collection, would become a historical document on the Venezuelan scientific reflections of the Nineteenth century. A few years later, and as an outgrowth of this initiative, the Sociedad de Ciencias Físicas y Naturales de Caracas was founded, under the initial direction of another German of repute: Adolfo Ernst.

Under the auspices of that scientific society, the most qualified discussions took place on anything that could be appreciated as a physical phenomenon, especially the subjects of mineralogy, meteorology and geology, unavoidably tied, by then, to the current explanation of earthquakes. Systematic quantification and measurements on the behaviour of nature captured the attention of the scientists, and thanks to their indefatigable work, today we can count on important data for cataloguing natural phenomena.

The academic attempts of these thinkers went beyond their scholarly discussions to be published in their own journal: Vargasia (with only seven editions, between 1868 and 1870) (fig. 2). From there, and in the space offered by newspapers of the time, enlightened researchers spoke of their scientific conclusions. After Ale- 
jandro Ibarra, the qualified members of the Sociedad de Ciencias Naturales continued the seismological discussion. Arístides Rojas (18261894), an active member, was one of the most outstanding in this area. His writings on Humboldt are famous (for instance, Humboldtianas, 1942), always accompanied by empirical efforts to contrast the hypotheses of the German, and his numerous articles in Venezuelan newspapers. Even more, Rojas maintained correspondence with scientists from all over the world, and saved their letters and exchanges of information, keeping an archive in which he filed more than fifty articles from national and international newspapers, on earthquakes, volcanoes and the origin of the Earth. This archive is conserved today in the Academia Nacional de la Historia de Venezuela (National Academy of History), in addition to thousands of other papers that at one time were part of his personal file.

Foreign scientists who spent time in the country, also contributed to the development of these discussions, as, for example, another German, Wilhelm Sievers, who dared to formulate interesting reasoning on 1812, published by Mittheilungen der Geographischen Gesellschaft zu

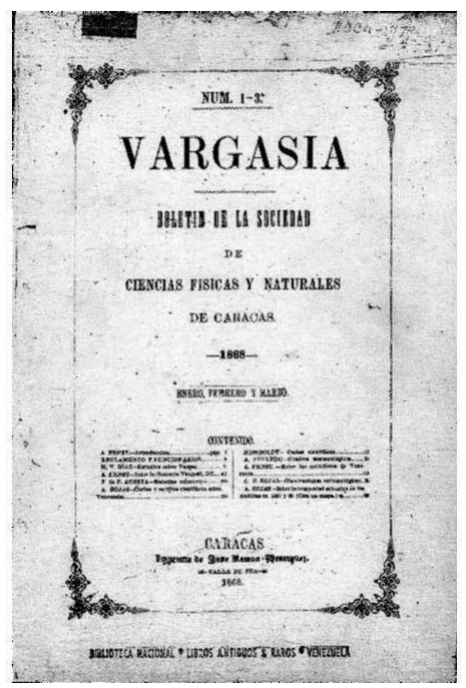

Fig. 2. Vargasia's cover. The journal was published between 1868 and 1870 in Caracas.
Hamburg (1884), following diligent field work in the mountains of Caracas. He introduced an element unappreciated at that time as a valid resource: the reading of documents contemporary to the disaster. His work received the angry answer by his compatriot Ernst (1886), in the Nederlands Aardrykskund Genoostrah, following which the discussion on that afternoon of 1812 was intensified and the debate on Venezuelan seismology command. Sievers (Sievers and Friedrichsen, 1895; Sievers, 1905) was to write again on earthquakes in Venezuela, after the great earthquakes of 1894 in Los Andes and 1900 in Caracas.

The Nineteenth century ended with a certain academic maturity in the equatorial regions of the enlightened Humboldt. Mixed between formality and amateur collecting, other tireless Venezuelans would contribute with important information in their works to the future of seismology in Venezuela. For example, Tulio Febres Cordero (1860-1938), editor, bequeathed invaluable data on the earthquake in the Andean region (table I), becoming, perhaps consciously, a historical collaborator in earthquake research (Febres, 1929 and 1991).

By then, at the doors of the Twentieth century, both great earthquakes mentioned before (1894 and 1900), had underlined the need for the construction of an exclusive and official space, and of systematic actions, to take care of the problems generated by a recurrent natural behaviour that was soon to be known as «disaster».

\section{The necessary specialization}

When on 28 April 1894, the Venezuelan city of Mérida collapsed once again in history (fig. 3 ), under one of the most devastating earthquakes of the region, the editorial office of the newspaper El Lápiz, edited by Tulio Febres Cordero, collapsed. Miraculously, Febres Cordero saved his life, unlike more than 300 people, or El Lápiz (which did not continue publication). The damage of that violent earthquake to churches, buildings, railways and the landscape in general, exposed to a great extent the impotence of all, spectators and victims, in the face of attacks by nature. Six years later, on 
A brief history of a restless vision: seismological research in Venezuela

Table I. Descriptive and Parametric Catalogues in Venezuela

\begin{tabular}{|c|c|c|c|c|c|}
\hline Authors & Funded by & Access & Date of edition & Time-window & Area \\
\hline $\begin{array}{l}\text { Tulio Febres } \\
\text { Cordero }\end{array}$ & Autofinancial & Public & 1929 & 1611-1929 & Andean region \\
\hline José Félix Soto & $\begin{array}{l}\text { Sociedad } \\
\text { Venezolana de } \\
\text { Ciencias Naturales }\end{array}$ & Public & 1931 & $1802-1918$ & Caracas \\
\hline $\begin{array}{l}\text { Melchor } \\
\text { Centeno Graü }\end{array}$ & $\begin{array}{l}\text { Academia de } \\
\text { Ciencias Físicas, } \\
\text { Matemáticas y } \\
\text { Naturales }\end{array}$ & Public & 1940 and 1969 & 1530-1949 & Venezuela \\
\hline $\begin{array}{l}\text { Observatorio } \\
\text { Cagigal }\end{array}$ & $\begin{array}{l}\text { National } \\
\text { Government }\end{array}$ & Public & 1959-1978 & 1959-1978 & Venezuela \\
\hline $\begin{array}{l}\text { EDELCA } \\
\text { (Electricidad } \\
\text { del Caroní) }\end{array}$ & Privado & Restricted & 1987-1999 & 1987-1999 & $\begin{array}{l}\text { Guayanese } \\
\text { region }\end{array}$ \\
\hline José Grases & PDVSA-INTEVEP & Restricted & 1979 & $1530-1977$ & Eastern region \\
\hline José Grases & PDVSA-INTEVEP & Restricted & 1980 & $1530-1977$ & Western region \\
\hline FUNVISIS & $\begin{array}{l}\text { National } \\
\text { Government }\end{array}$ & Public & 1983- & $1983-$ & Venezuela \\
\hline $\begin{array}{l}\text { José Grases, } \\
\text { Rogelio Altez } \\
\text { and Miguel Lugo }\end{array}$ & $\begin{array}{l}\text { Academia de } \\
\text { Ciencias Físicas, } \\
\text { Matemáticas y } \\
\text { Naturales, Universidad } \\
\text { Central de Venezuela }\end{array}$ & Public & 1999 & 1530-1998 & Venezuela \\
\hline
\end{tabular}

29 October 1900, Caracas and a vast extension of the coast to the north of the city, facing the Caribbean Sea, suffered the last earthquake of the Nineteenth century and first of the Twentieth century. Once again, that symbolic boundary illustrated important transformations in the Venezuelan society of the times.

While Caracas and its surroundings succumbed during the 1900 earthquake, two great researchers of earthquakes initiated methodology for advancing knowledge of earthquakes, going so far as to mention the responsibility of geological faults as their origin. The scholars at issue are J. Milne (1850-1913) and Montessus de Ballore (1851-1923), and the methodological resource, of course, was the cataloguing of events. Milne compiled information on destructive events, which «...probably were the result of the formation or extension of geologic faults» (Grases, 1986), in a catalogue (Milne, 1911) presented at the meeting of the BAAS (The British Association for the Advancement of Science), in 1911, held in Portsmouth. Montessus de Ballore (1915-1919), at the same time, put together an extensive archive of manuscripts with a combined total of 90 feet of shelves, containing information on earthquakes totalling 171434 entries (Grases, 1986).

It was a time of precursors. In Caracas, and thanks to the earthquake of 1900 , the first map with intensity contours elaborated by a Venezuelan was published in the newspaper La Linterna 
Mágica (Caracas, 15 November 1900). The author, engineer Melchor Centeno Graü (18671949), steered the necessary course: that of specialists. Considered the pioneer of seismology in Venezuela, his greatest contribution was, indeed, the first earthquake catalogue published in this country (Centeno Graü, 1940) (table I). Previously, important «lists» had been elaborated by other contemporary researchers. One of those was that of his colleague José Félix Soto, titled «La sismología en Venezuela» (The Seismology in Venezuela) and published by the Boletín de la Sociedad de Ciencias Naturales (Bulletin of the Natural Sciences Society), in 1931. Nevertheless, the work of Centeno exceeded all the previous work made in this country.

With the title of «Estudios Sismológicos», (Seismological Studies) in 1940, Centeno Graü published a catalogue preceded by an introductory study in which he carefully explained all the current theories on earthquakes, accompanying them with his own hypotheses on the matter. He reviewed all the earthquakes that he was aware of, not having been a documental researcher. $\mathrm{He}$ illustrated his work with pictures, figures and maps, to which he added details that had not been taken into account before, such as the assessment of damage and the time of the events. He tried to establish periods of recurrence, calculating cycles of destructive earthquakes, based on chronological criteria. He used the scale of Mercalli and concentrated on earthquakes between intensity VII and X. He established bonds with geology, volcanism and other risks (Grases et al., 1999). He also discussed the 1812 earthquake, indicating that it was a «polycentric seism» and of simultaneous action (Altez, 2000b). The Academia de Ciencias Físicas, Matemáticas y Naturales de Venezuela (Academy of Physical, Mathematical and Natures Sciences) would publish in 1969 a second, amplified edition of Centeno's catalogue (Centeno

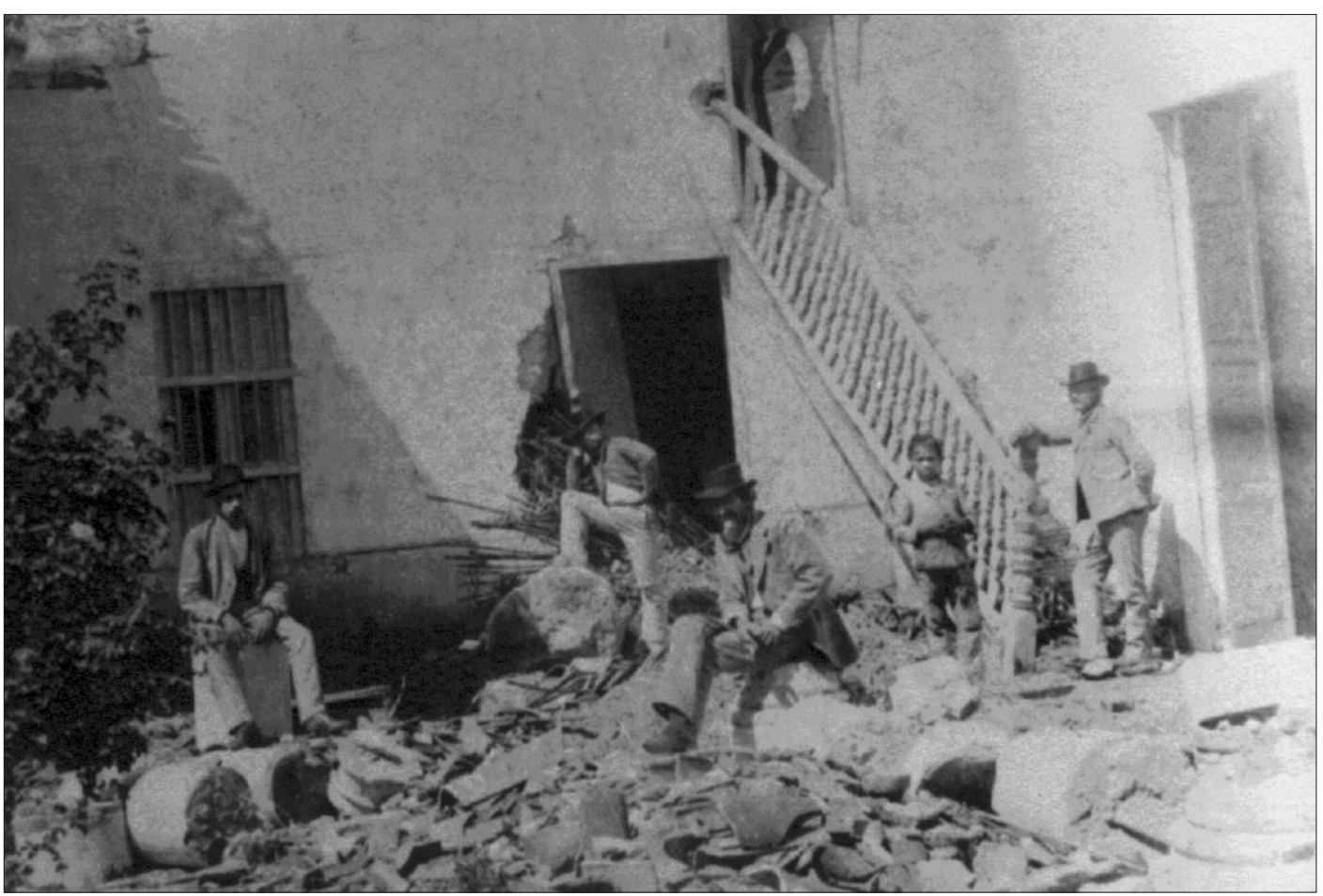

Fig. 3. Damage caused by the earthquake of 1894 in Mérida, Venezuela (from Romero, 1894). 
Graï, 1969), with the addition of some details that were taken from his notes after his death.

That study was the basis of the knowledge of seismic history in Venezuela for decades, and the only published catalogue until 1999 (table I). Meanwhile, another German, Günter Fiedler, was to contribute to Venezuelan geological research. Having arrived in Caracas after World War II, Fiedler entered the scientific scene with his presentation in the III Congreso Geológico Venezolano (III Geological Congress of Venezuela, 1961), «Areas afectadas por terremotos en Venezuela» (Areas affected by earthquakes in Venezuela) (1961). Later, in the IV Congress of the same discipline, in his paper on «La liberación de energía sísmica en Venezuela, volúmenes sísmicos y mapas de isosistas» (The liberation of seismic energy in Venezuela, seismic volumes and isoseismal maps) (1969), like many of his predecessors, he would give his opinions on the earthquake of 26 March 1812 (fig. 4), affirm- ing that there were three earthquakes with different epicentres, where one could have triggered the others, with an imperceptible difference between them (Fiedler, 1969).

In the aftermath of the most destructive earthquakes in the history of Venezuela, seismological research inserted its discourse and made its advancements. The best example, perhaps, is that of 1812, which even today generates serious controversy. Fiedler would be an important protagonist in setting this course in the science of earthquakes in Venezuela. Later, in 1967, when the last destructive earthquake of Caracas occurred, the German thinker would be in charge of the Observatorio Cagigal (Cagigal Observatory), and would observe, with frustration, how the force of the movement caused the collapse of the instruments located there. Again, an earthquake marked great changes in seismological observation in Venezuela. After 1967, the earthquake issue would become an official matter.

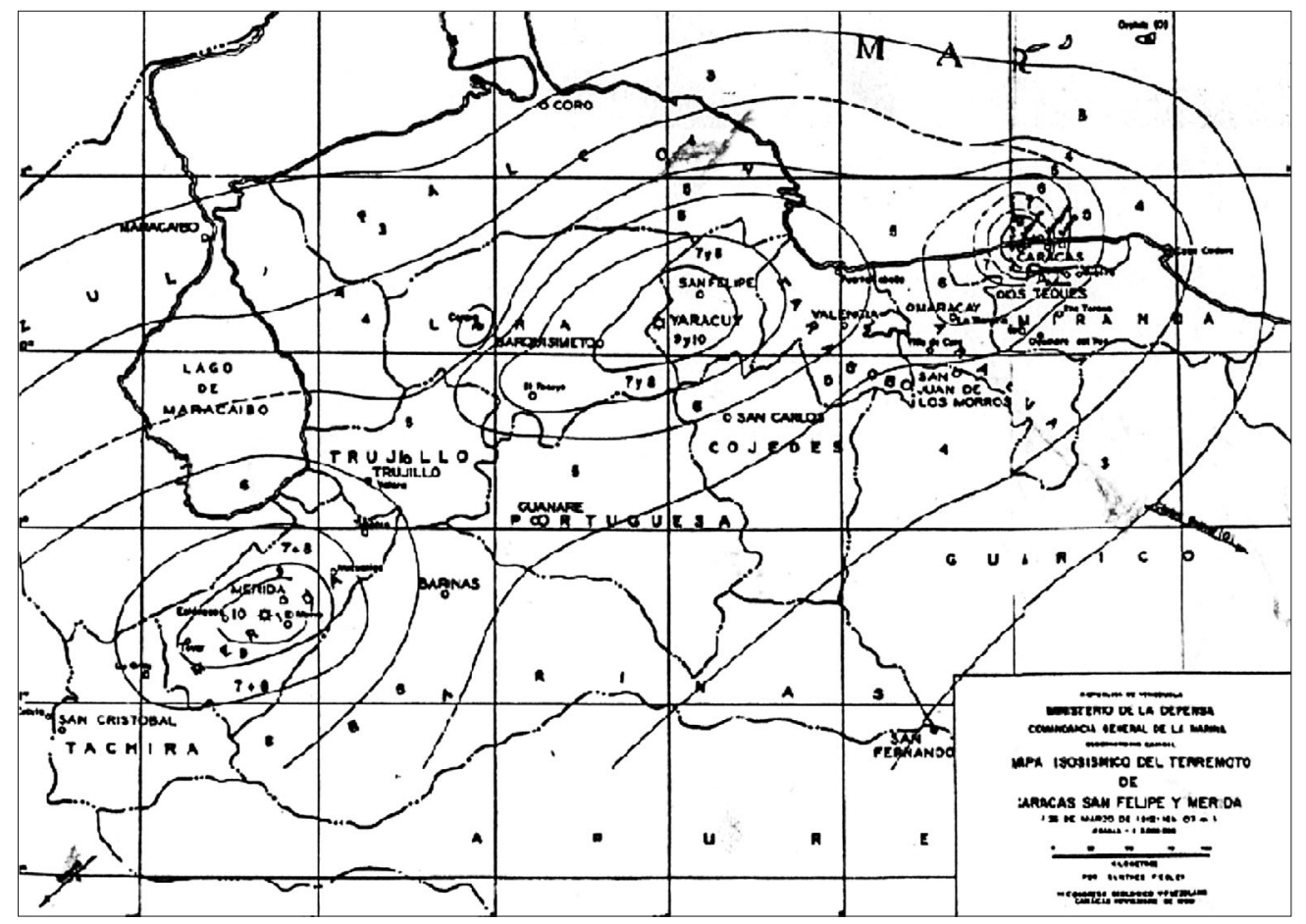

Fig. 4. Map of intensities for 1812, from Fiedler (1969). 


\section{Instruments and institutions}

The appearance of applied technology, and its uses in research and knowledge, was one of most important advances in seismological research at the turn of the 20th century. In Venezuela, with the creation of the Observatorio Cagigal, in 1889 , the formal monitoring of natural phenomena was made official. In 1901 two seismographs were installed; a pair of rudimentary instruments, Agamennone and Ewing (Salas, 1990), unfortunately no bulletins of their performances have been found. However, Hubschmann (1988) alleged the existence of an instrumental registration of seismic movement by means of a horizontal pendulum used by Henri Pittier, prior to the seismographs of the observatory.

In any case, the new century began to give signs of what would be its fundamental characteristic: technology. Instrumental seismology, the fundamental resource for research and monitoring of earthquakes, was now being carried out in an accurate institutional context. Advancement in this field obviously depended on governmental decisions. Only after the occurrence of a destructive earthquake in the capital of the country, were the necessary steps taken towards the consolidation of seismological research and the financing of technological development. Soon after the 1967 earthquake, the Fundación Venezolana de Investigaciones Sismológicas (FUNVISIS, Venezuelan Foundation of Seismological Investigations) was created (1972). In this way, a specialized institution was born, exclusively dedicated to observation and seismological analysis. FUNVISIS would be in charge of the creation of alarm networks, and for the installation of observation stations all over the country, as well as the production of knowledge, through research and explorations.

The occurrence of a destructive event was necessary for the seismic history of Venezuela to be remembered. Probably, this experience has been repeated around the world; nevertheless, even more alarming than the fact that this is a common variable, is the fact that it has reccurred in spite of previous experiences. It is for that reason that it took so long for the political and scientific world to understand that the problem is not one of assistance, but the prevention of disasters.

\section{Researchers, criteria and discussions}

After the work of Fiedler, Venezuela has counted on the contributions of investigators of long standing, some of them still producing. Over the last decades, the research of André Singer stands out; he is, perhaps, the most brilliant geomorphologist in the country. French of birth, Singer become FUNVISIS president, after many years as chair of the Departamento de Ciencias de la Tierra (Department of Sciences of the Earth). There he was in charge of promoting documentary research, initiating a research project that has not yet found an heir: the Inventario nacional de riesgos geológicos (National Inventory of Geological Risks), which produced a preliminary publication in 1982 (Singer et al., 1982). Innumerable articles enrich the shelves of FUNVISIS through his research.

Another Venezuelan of German heritage, Carlos Schubert, geophysicist, also dedicated years of his life to the study of earthquakes, and standing out among his more than eighty scientific writings, is his book «Los terremotos en Venezuela y su origen» (The earthquakes in Venezuela and their origin, 1982), a didactic manual for general consultation. Also notable are the contributions of José Grases, Venezuelan engineer who initiated his study of earthquakes after his observation of the effects of the 1967 earthquake on the buildings of Caracas (Grases, 1979, 1980, 1986 and 1990; Grases et al., 1999).

The catalogue by Grases et al. (1999) deserves a special commentary. As we indicated earlier, the catalogue of Centeno was the only published catalogue available in Venezuela following its first edition in 1940, illustrating the lack of attention in this country regarding seismological cataloguing, and the official uninterest in historical and documentary research. In effect, even though in FUNVISIS efforts were made to include in their publications historical knowledge of Venezuelan geological activity, those pieces of research only figured under the title of «historical seismicity», and only attained descriptive levels. Only occasionally were those levels extended to embrace an interpretative scope. The elaboration of a seismological catalogue, naturally, has to be the duty of the official institution that systematically in- 
vestigates earthquakes; nevertheless, the initiative was developed outside its offices and depended on external academic financing. At the same time, the catalogue published by Grases et al. (1999) is also a revision and update of the pioneering work of Centeno, taking it as its basis, displaying information, correcting and extending if necessary, and adding the results of years of documentary research.

At the present time, the researchers related to historical seismology in all parts of the country, are following up an initiative that took its first step in 1997, when in the Andean city of Trujillo, the Primeras Jornadas de Sismicidad Histórica (First Meeting of Historical Seismicity) was held. Today, following three of those seminars, they have changed their name to Jornadas de Sismología Histórica (Meeting of Historical Seismology), in recognition that the works presented go beyond the descriptive levels and attempt to produce systematic knowledge. These efforts are supported by FunVISIs, the Universidad de Los Andes (University of Los Andes), the Universidad Central de Venezuela and the Sociedad Vene- zolana de Historia de las Geociencias (Venezuelan Society of History of the Geosciences). Interestingly, 26 March 1812 is still being discussed there...

At the first event of 1997, an anthropologist presented a work titled «Cronometrización extemporánea, los sismos del 26 de marzo de 1812 en Caracas y Mérida» (Untimely chronometry, the earthquakes of March 26th of 1812 in Caracas and Mérida) (Altez, 1998), where he demonstrated that not one earthquake destroyed so many cities at the same time, but that there had been two earthquakes with one hour difference occurring, the first at 04:07 p.m. in Caracas (fig. 5), and the second about five o'clock in the afternoon in Mérida. These conclusions were based on documentary research supported by the knowledge of the seismologists of FUNVISIS. After so many decades of discussion and with debates that span three different centuries, the events of 1812 continue to provoke controversy, establishing a transhistorical dialogue among researchers who follow the steps of Humboldt or Sievers, Fiedler or Ernst, victims or witnesses.

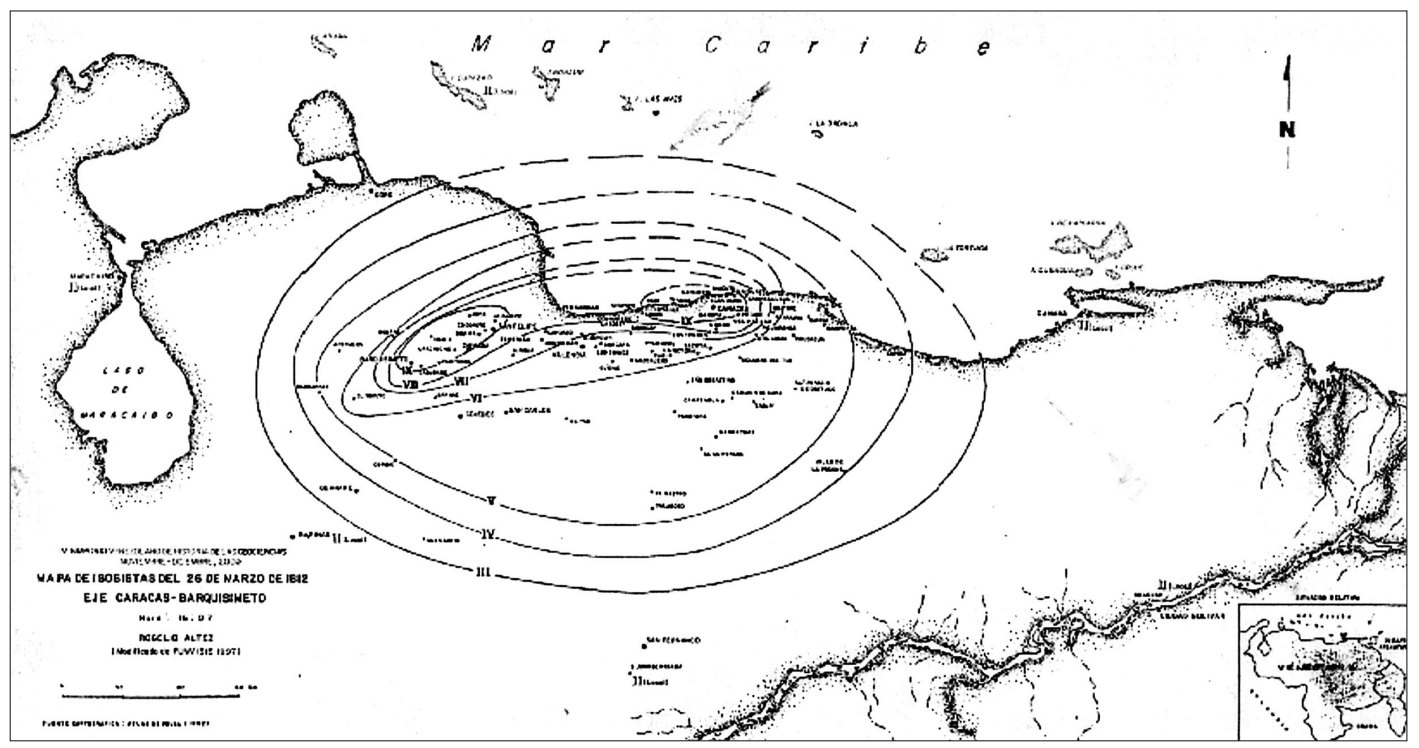

Fig. 5. Map of intensities for the 1812 earthquake in Caracas (Altez, 2000b). 


\section{Catalogues and sources}

It has been shown above that cataloguing has received very little stimulus in Venezuela. From the listings and chronologies of the Nineteenth century, elaborated by amateurs and collectors, through the academic attempts to obtain knowledge of Nature's behaviour from the repetition of the events, catalogues have been isolated efforts with no continuity (table I). In fact, although Centeno's work is known as a «catalogue», it is an inventory of dates and data, that can be called «chronology». Certainly, a chronology, or «chronological list», it is based on the idea of presenting the repetition of natural phenomena in an orderly way. That is the quality of the works that were elaborated before the understanding of the meaning of the cataloguing. However, Centeno's work changed the theoretical support of chronologies and gave the first steps toward a new understanding of historical earthquakes.

Among lists and amateur studies, in 1929, Tulio Febres Cordero would publish his «Cronicón sísmico» (Seismic Chronicle); later, as already mentioned, José Félix Soto would publish «La sismología en Venezuela» (1931); and Centeno would initiate his «Estudios sismológicos» (1940), that would take years to be followed up; also, the Observatorio Cagigal would publish the result of its activities in its Boletines sísmicos mensuales (Monthly Seismic Bulletins) (19591978), which covered the period between 1959 and 1978. Nevertheless, it must be noted that at least from 1979, the intention has existed to catalogue the seismic activities of the country in some official institutions. This intention however, has not necessarily been in the public domain or available for consultation.

As an example, PDVSA, one of the main companies in charge of oil exploration in Venezuela, and one of the main financial supporters of seismological research, has sponsored studies, through its branches, fundamentally INTEVEP. They produced a pair of important catalogues previous to the one of 1999, but they were not available to the public: both were the work of Grases (1979 and 1980), and are reserved for specialised consultation for official state research. Later, the institutions would understand the importance of cataloguing, at least from the instru- mental bulletins, thus producing information of utility for their interests. Consequently, lists were elaborated of instrumental bulletins without interpretative intent and strictly designed for technical use. The Boletines sísmicos mensuales de la red de Guri (Monthly Seismic Bulletins of Guri Network) (EDELCA, 1987-1999), the Boletin sismológico de Venezuela (Seismologic Bulletin of Venezuela) (FUNVISIS, from 1983), and the Catálogo de sismos registrados instrumentalmente con epicentro en Venezuela (Catalogue of instrumentally-registered earthquakes with epicentres in Venezuela) (FUNVISIS-INTEVEP, 1993), are examples that illustrate this situation. These are catalogues based only on instrumental monitoring and not integral cataloguing that includes historical information.

In fact, it would appear that a certain epistemological criterion underlies the elaboration of these lists of registrations, which seems to acknowledge a split between the «instrumental» and «historical», as if they existed in different and disconnected worlds. From this stance, the «historic» is perceived as irrelevant and documentary registers are interpreted as failed interpretations from a context already surpassed discursively and theoretically. In 1886, in answer to the efforts of Sievers to interpret the 1812 earthquake, Adolfo Ernst replied forcefully:

«I have looked in vain in the local archives for more documents and I have only found in the Palacio Arzobispal some data sent by the parish priests from diverse localities to the superior ecclesiastical authorities; nevertheless, for the geological history of the earthquake, they completely lack value» (Ernst, 1886, p. 481, translation by the authors).

In spite of the temporal distance, these methodological criteria still seem to be held by many of the researchers of the present time.

Probably, one of the main reasons behind that position, although it is not assumed as transparently as by the German scholar of the Nineteenth century, has to be the practical ignorance of documentary handling. It is difficult to find geologists, seismologists, engineers or geophysicists, with adequate preparation in paleography or knowledge of primary sources, in spite of the interest they may profess. This is an unavoidable limit to the seismological perspective. 
There are only a few occasions in Venezuela when it is possible to appraise the effort to integrate several methodological resources and different epistemological tools. The already mentioned Jornadas de Sismología Histórica, have provided spaces for the effort of the researchers concerning the historical knowledge of earthquakes. These gatherings promote discussions among investigators coming from different branches of science: geophysicists, geomorphologists, historians, anthropologists, engineers, geologists, geographers, topographers and many students. In the last few years, the more stimulating papers have been a good example of it: Christl Palme, geophysicist, with her research on the earthquakes of 1674 (Palme, 1993; Palme and Altez, 2002); the works of the geomorphologist Carlos Ferrer and also the geophysicist Jaime Lafaille on the events of 1610 and 1812 (1998 and 2000); one of the works of André Singer, «Contribución de Simón Rodríguez a la emancipación científica independentista latinoamericana...» (2000); the research of Altez on 1812 (1998, 1999, $2000 \mathrm{~b}$ and 2000c); the catalogue of Grases et al., (1999); and the article by the engineer Jose Antonio Rodriguez on the earthquake of Cumaná of 1929 (1998). Separate mention must be made of the dedication and the contribution of Franco Urbani, in charge of the Sociedad Venezolana de Historia de las Geociencias, which has published dozens of historical documents related to geology, seismology and the geography of Venezuela, through the Boletín de Historia de las Geociencias en Venezuela (Bulletin of Venezuelan Society of History of Geo-sciences), with 71 volumes from its creation in 1984 (e.g., Urbani, 1990).

This effort to coordinate an interdisciplinary vision is, certainly, a multifaceted link between natural sciences and primary sources. The knowledge of historical processes and the knowledge of the behaviour of the active faults have been interlinked. Also, the need to know possible periods of recurrence forced the investigators to look at the colonial past and the Nineteenth century, telluric places of irretrievable data for the physical sciences. For that reason, the information contained in Centeno's catalogue provided initial, although often insuf- ficient, historical background for seismological research. Even in Centeno's catalogue there are very few references for the first four centuries of history of the region. Between the first entry of that work, referring to 1 October 1530, and 1900 , there are only 36 pages of information. In the catalogue by Grases et al. (1999), those four centuries fill 245 pages with data collected in primary and direct sources, all of them accompanied by their documentary references.

This difference between the two catalogues is, above all, qualitative. It is the result of the concrete interest and the need to know those processes better. Works previous to the catalogue peeked into that past, sometimes gropingly, and others with certainties rarely reached among historians. Punctual research, such as that financed by the oil companies, provided documentary revelations on events of the past. The engineers doing these researches were forced to go through piles of mouldy, dusty manuscripts and indecipherable handwriting. At that time, the best solution was to contract documentary specialists. However, from the discussion between social and natural scientists, the idea was born to create its own space, such that of the Jornadas. This was a methodological recognition that Singer noted in his words of opening:

«Before World War II, in their own field and for restricted global scales of time incomparably more restricted, historians faced the same problem confronted by the seismologists of the necessity of an analogous widening of the «time window» at the time of the development of the well-known Historical School of Annals of Economic and Social History arises in France, headed by Marc Bloch, Lucien Febvre and Fernand Braudel. This school of thought contributed to the interdisciplinary bases necessary to unify the understanding of long term historical phenomena relative to the trends the economic fluctuations, and the daily vicissitudes of micro-history, corresponding to the development of the diverse forms of life of the men, policy, military, religious and artistic». (Singer, 1998, pp.18-19, translation by the authors).

However, the handling of those sources still continues being the art of specialists. But knowing the documentary repositories does not mean 
necessarily an understanding of the semantic content of texts, nor the ability to interpret them in a seismological way. Even more, information production, which is directly determined by the historical contexts, is elaborated and structured semantically in relation to hermeneutic senses different from those in the present. This is why what is reflected in a text from the past, literally means what it exposes. In order to understand it, an interpretative effort that knows much more than the palaeographic techniques is needed: it must differentiate the discourse of the context, which implies, therefore, knowledge of the mindset of that context:

«The elaboration of information that a society produces daily, either from its official instances, or from its own protagonists, is always in coherence with the fundamental structures of that society. In that sense, the information has particular characteristics that identify it with the historical processes to which it belongs. For that reason, the structural differences that separate the Colonial model from the Republican, for example, also will create substantial distances in information production» (Grases et al., 1999, p. 16, translation by the authors).

Therefore, information is the result of putting into practice the reading of the reality that its context contains; consequently, the quality and the amount of that information also are determined by the same circumstances. For that reason, the common direction that has been used for the search of information in the past on the part of the researchers has been, generally, one that uses as a starting point the date of the event, when in fact, to arrive at the event, the direction has to be inverse: it must go in the first instance, to the context of the society of the time, which places the information produced in relation to the event. It is not the fact that guides the information, but its context.

Before there was awareness of this methodological strategy, the seismic silence of the region in the first centuries of history was much greater. In the case of the colonial past, much of the information that appeared for the 1999 catalogue, was the outcome of a two-vectored search: one of them concentrated in the information on geographical relations, prospective mineral searches (both coincident with the
Spanish strategy of precious metals) and travellers; the other, aimed toward the history of the churches. The latter proved richer documentarily and equipped with a determining variable for the case: they were the only buildings of the time, that is to say, they were the best witnesses of damage and ruins.

More surprising is the seismic silence from the Nineteenth century, where there was better access to the interpretation. Nevertheless, except for the most destructive earthquakes, almost nothing was known of other earthquakes. Again, the knowledge of the contexts facilitated the search:

«It is for these reasons, fundamentally, that the first decades of the republican life of Venezuela show a seismic «silence» that surely cannot be taken as a faithful testimony of the geologic reality. If the Earth moved and it did not destroy that which remained after the war and the earthquake of 1812, who would care? It would be necessary to wait for a few decades so that the newspapers proliferated, diversified their contents, and promoted columns on the opinions of scientists and students of nature. The negligible information on earthquakes found for the years between 1812 and 1853, is a faithful witness to this» (Altez, 2000a, p. 471 , translation by the authors).

In the catalogue of Centeno, between 1812 and 1853 there are only 13 entries in three pages; in the 1999 catalogue, for the 1812 earthquakes alone there are 26 pages. This evidence regarding information is the reflection of the need for a methodological transformation in the search of data. It is, finally, the recognition of an interpretative change, or a hermeneutic turn, in seismological research. It is a necessary turn that gently moves to unite the multiple visions of the sciences, perhaps an insight leading to the inescapable idea of only one science.

\section{REFERENCES}

Altez, R. (1998): Cronometrización extemporánea: los sismos del 26 de marzo de 1812 en Caracas y Mérida, Rev. Geogr. Ven. (Facultad de Ciencias Forestales y Ambientales, Instituto de Geografía y Conservación de Recursos Naturales, ULA, Mérida), 297-325.

AlteZ, R. (1999): Lo que el terremoto se llevó: los razonamientos de Humboldt sobre el 26 de marzo de 1812, in Alemanes en las Regiones Equinocciales, edited by J.Á. RODRÍGUEZ (Alfadil Ediciones-AVH-Stiftung- 
FHE/UCV, Caracas), 111-127.

Altez, R. (2000a): Desastres y conocimiento: breve ensayo sobre la mirada histórica de la sismología, in $\mathrm{Vi}$ siones del Oficio, Historiadores Venezolanos en el Siglo XXI, edited by J.A. RoDRíGUEZ (Academia Nacional de la Historia-Facultad de Humanidades y Educación-Universidad Central de Venezuela, Caracas), 453-474.

Altez, R. (2000b): Los sismos del 26 de marzo de 1812 en Venezuela: nuevos aportes y evidencias sobre estos eventos, Bol. Soc. Ven. Hist. Geocien. (forthcoming).

Altez, R. (2000c): Terremotos Confundidos: los Sismos del 26 de Marzo de 1812 in Caracas y Mérida, Bolivarium, Anuario de Estudios Bolivarianos (Universidad Simón Bolívar, Caracas), 9, 1-32.

Centeno Graü, M. (1900): El terremoto del 29 de Octubre, La Linterna Mágica (Caracas), 15 November, 1-2.

Centeno Graü, M. (1940): Estudios Sismológicos, (Litografía del Comercio, Caracas), 1st edition.

Centeno Graü, M. (1969): Estudios Sismológicos, Academia Nacional de Ciencias Físicas, Matemáticas y Naturales (Talleres Tipo-Litográficos de la Dirección de Cartografía Nacional, Caracas), 2nd edition.

EDELCA (1987-1999): Boletines Sísmicos Mensuales de la Red de Guri (Puerto Ordaz, Venezuela).

ERnst, A. (1886): Das Erdbeben von 26 März, 1812, an der Nordküste Südamerikas (Nederlands Aardrykskund Genoostrah.), Ser. II, Deel III, 1, 175-181.

Febres, C.T. (1929): Cronicón Sísmico, El Universal, (Caracas), 2 March, p. 5.

Febres, C.T. (1991): Obras Completas (Talleres de Litografía, San Cristóbal, Venezuela).

Ferrer, C. and J. LAFAille (1998): El alud sísmico de La Playa: causas y efectos. El terremoto de Bailadores de 1610, Rev. Geogr. Ven. (Facultad de Ciencias Forestales y Ambientales, Instituto de Geografía y Conservación de Recursos Naturales, ULA, Mérida), 23 86.

FIEDLER, G. (1961): Áreas Afectadas por terremotos en Venezuela, in III Congreso Geológico Venezolano (Editorial Sucre, Caracas), 1796-1797.

FIEDLER, G. (1969): La Liberación de Energía Sísmica en Venezuela, Volúmenes Sísmicos y Mapas de Isosistas, IV Congreso Geológico Venezolano (Editorial Sucre, Caracas), 2441-2462.

FUNVISIS (from 1983): Boletín Sismológico de Venezuela (Departamento de Sismología, Caracas).

FUNVISIS-INTEVEP (1993): Catálogo de Sismos Registrados Instrumentalmente con Epicentro en Venezuela (FUNVISIS-INTEVEP, Caracas).

Grases, J. (1979): Investigación Sobre los Sismos Destructores que han Afectado el Oriente de Venezuela, Delta del Orinoco y Regiones Adyacentes (INTEVEP, Caracas).

Grases, J. (1980): Investigación Sobre los Sismos Destructores que han Afectado el Centro y Occidente de Venezuela (INTEVEP, Caracas)

GRASES, J. (1986): Hacia la reconstrucción de la historia de los terremotos del Caribe, Rev. Geofís. (Instituto Panamericano de Geografía e Historia, January-June), 24, 53-69.

Grases, J. (1990): Terremotos Destructores del Caribe, 1502-1990 (UNESCO-RELACIS, Montevideo), pp. 132.
Grases, J., R. Altez and M. Lugo, (1999): Catálogo de Sismos Sentidos o Destructores: Venezuela, 1530-1999 (Academia de Ciencias Físicas, Matemáticas y Naturales/Facultad de Ingeniería, UCV, Caracas).

Hubschmann, K. (1988): Observatorio Cagigal, Cien Años de Historia y de Ciencia (Lagoven, Caracas).

Humboldt, A. VON (1956): Viaje a las Regiones Equinocciales del Nuevo Continente (Ediciones del Ministerio de Educación, Caracas).

IbArRA, A. (1854): Temblores y lluvias en Caracas, Diario de Avisos (Caracas), 2 September, p. 2.

IBARRA, A. (1862): Temblores y terremotos, El Independiente, (Caracas), March-April.

LAFAille, J. and C. FerRer (2000): El terremoto del jueves santo en Mérida: año 1812, II Jornadas de Sismicidad Histórica (Mérida) (forthcoming).

LEAL, H. (1994): La Enseñanza de la Física en la Universidad Central de Venezuela, 1827-1880, Fuentes para la historia republicana de Venezuela (Academia Nacional de la Historia, Caracas).

Lemoine, W. and M.M. SuÁrez (1984): Beauperthuy, de Cumaná a la Academia de París (UCAB-IVIC, Caracas).

Milne, J. (1911): A Catalogue of Destructive Earthquakes A.D. 7 to A.D. 1899, BAAS (London), pp. 92.

Montessus De Ballore, F. de (1915-1919): Bibliografía General de Temblores y Terremotos, Sociedad Chilena de Historia y Geografía (Imprenta Universitaria, Santiago de Chile).

OBSERVATORIO CAGIGAL (1959-1978): Boletines sísmicos Mensuales (Caracas).

PALACIO FAJARDO, M. (1816): An account of the earthquake of Caracas, Quarterly J. Sci. (London), 3, 337-348.

Palme, C. (1993): Los Terremotos de los Años 1674, 1775 y 1886 en Trujillo (Departamento de Física y Matemáticas, Universidad de los Andes, Caracas).

Palme, C. and R. Altez (2002): Los Terremotos de 1673 y 1674 en los Andes venezolanos, Interciencia (Caracas), 27 (5).

RoDRÍGUEZ, J.A. (1998): De la sismicidad histórica a la sismicidad instrumental: el terremoto de Cumaná de 1929, Rev. Geogr. Ven. (Facultad de Ciencias Forestales y Ambientales, Instituto de Geografía y Conservación de Recursos Naturales, ULA, Mérida), 189-202.

RoJAs, A. (1942): Humboldtianas (Editorial Cecilio Acosta, Caracas-Buenos Aires).

ROMERO G., P. P. (1894): Fotografías de daños ocasionados por el Gran Terremoto de los Andes, Colección Venezuela Siglo XIX, Archivo Audiovisual, Biblioteca Nacional (Caracas).

Salas, H. (1990): Primeros sismógrafos en Venezuela, Boletín de Historia de las Geociencias en Venezuela (Sociedad Venezolana de Historia de las Geociencias, Caracas), 39, 1-16.

SCHUBERT, C. (1982): Los terremotos en Venezuela y su origen (Lagoven, Caracas).

SIEvERS, W. (1884): Das Erdbeben von 26 März, 1812, an der Nordküste Südamerikas, Mittheilungen der Geographischen Gesellschaft zu Hamburg, 265-271 (a facsimile copy).

SIEVERS, W. (1905): Das Erdbeben in Venezuela von 26 Oktober 1900, Jahrb. Veroffnet. Geogr. Ver. (Bonn), 35-50 (a facsimile copy).

SIEvers, W. and L. FriederichSEN (1895): Das Erdbeben 
in Venezuela von 28 april 1894, Mittheilungen der Geographischen Gesellschaft zu Hamburg, 10, 237-244.

Singer, A. (1998): Palabras de apertura a las Primeras Jornadas de Sismicidad Histórica, Rev. Geogr. Ven., (Mérida), 39 (1-2), 17-21

Singer, A. (2000): Contribución de Simón Rodríguez a la emancipación científica independentista latinoamericana: su papel como precursor de los estudios de microzonificación sísmica en Concepción, Chile, II Jor- nadas de Sismicidad Histórica, Mérida, (forthcoming). Singer, A., C. Rojas y M. Lugo (1982): Inventario Nacional de Riesgos geológicos, Estado preliminar, (FUNvisis, Caracas).

Soto, J. F. (1931): La sismología en Venezuela, Bol. Soc. Ven. Cien. Nat., 2, 37-89.

Urbani, F. (1990): Manuel Palacio Fajardo (1784-1819) y su contribución a las ciencias naturales, Bol. Hist. Geoc. (Caracas), 40, 24-30. 